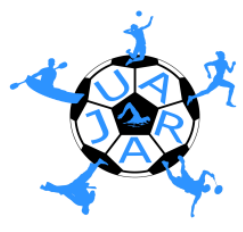

JUARA: Jurnal Olahraga

E-ISSN 2655-1896 ISSN 2443-1117

https://doi.org/10.33222/juara.v5i2.759

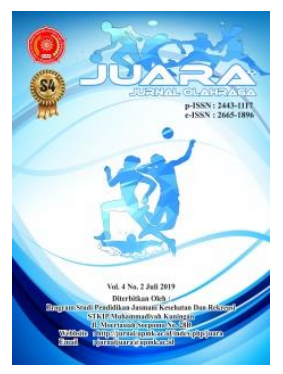

\title{
Latihan Sirkuit Signifikan Menurunkan Berat Badan dan BMI
}

\section{Circuit Training Significantly Reduce Body Weight and BMI}

Denny Ramdhanni ${ }^{1}$, Pipit Pitriani ${ }^{2}$,Mulyana ${ }^{3}$.

1,2 Postgraduate in Physical Education, Universitas Pendidikan Indonesia, Jl. DR. Setiabudi No.229, Isola, West Java Province, 40154, Indonesia

${ }^{3}$ Faculty of Physical Education and Health, Universitas Pendidikan Indonesia, Jl. DR. Setiabudi No.229, Isola, West Java Province, 40154, Indonesia

email: dennyramdhani30@gmail.com ${ }^{1}$, pipitpitriani@upi.edu ${ }^{2}$, mulyanafpok@upi.edu ${ }^{3}$

\section{Info Artikel Abstrak}

Sejarah Artikel:

Diterima 09 November 2019

Disetujui 05 Mei 2020

Dipublikasikan 27 Mei 2020

Keywords:

Body Mass Index, circuit training, obesity.
Tujuan dari penelitian ini adalah untuk melihat pengaruh latihan sirkuit terhadap berat badan dan indeks massa tubuh. Penelitian ini menggunakan metode penelitian eksperimental. Subjek penelitian berjumlah 22 orang wanita gemuk didapat dengan teknik purvosive sampling yang memiliki Indeks Massa Tubuh $\left(25 \mathrm{~kg} / \mathrm{m}^{2}-30 \mathrm{~kg} / \mathrm{m}^{2}\right)$ Instrumen yang digunakan pengukuran berat badan dan tinggi badan kemudian dihitung Indeks Massa Tubuhnya dengan rumus IMT= $B B(\mathrm{~kg}) / T B\left(\mathrm{~m}^{2}\right)$. Berdasarkan hasil penelitian latihan sirkuit signifikan menurunkan berat badan dan indeks massa tubuh. Oleh karena itu dapat disimpulkan bahwa program latihan sirkuit training dapat mempengaruhi berat badan dan IMT pada wanita obesitas.

\begin{abstract}
The purpose of this study was to investigate the effect of circuit training on body weight and body mass index. This research uses experimental research methods. The subjects of the study were 22 obese women with classification $\left(25 \mathrm{~kg} / \mathrm{m}^{2}-30 \mathrm{~kg} / \mathrm{m}^{2}\right)$ and sampling used was a purposive sampling technique. The instrument used was BMI (Body Mass Index) with the formula $B M I=B B(\mathrm{~kg}) / T B\left(\mathrm{~m}^{2}\right)$. Based on the results, circuit training significantly reduced body weight and body mass index. Hence, it can be concluded that there is an effect of circuit training on body weight and BMI in obese women.
\end{abstract}

\footnotetext{
${ }^{\square}$ Alamat korespondensi: J1. DR. Setiabudi No.229, Isola, West Java Province, Indonesia

E-mail : dennyramdhani30@gmail.com
} 


\section{PENDAHULUAN}

Obesitas telah meningkat secara signifikan. Secara global, pada tahun 2016, $13 \%$ orang dewasa berusia 18 tahun atau lebih (11\%) pada pria; $15 \%$ pada wanita) mengalami obesitas, dan $39 \%$ orang dewasa berusia 18 tahun atau lebih tua $(39 \%$ pada pria; $40 \%$ pada wanita) kelebihan berat badan (Ng et al. 2014). Peningkatan obesitas di Indonesia tahun 2010 sebesar $11.7 \%$ menjadi $15.4 \%$ tahun 2013 berdasarkan (Kementrian Kesehatan RI, 2018). Menurut WHO tahun 2011 diperkirakan meningkat pada tahun 2025 sebesar 50\%. Obesitas menjadi Indikator Pembangunan Nasional RPJMN tahun 2015-2019 dan Renstra Kemenkes tahun 2015-2019. Obesitas telah menjadi masalah kesehatan dan mengancam keberhasilan pembangunan nasional. Keberhasilan Pencapaian Indikator Pembangunan Nasional RPJMN Tahun 20152019 ditentukan dari Komitmen semua pihak.

Obesitas menjadi kontributor utama terhadap beban penyakit global, dengan perkiraan prevalensi saat ini $5 \%$ pada anakanak dan $12 \%$ pada orang dewasa, mewakili lebih dari dua kali lipat meningkat sejak 1980 (Gregg, Ph, and Shaw, 2017). Data terbaru menunjukkan bahwa tren peningkatan obesitas lebih banyak pada wanita (Flegal et al. 2013). Obesitas dapat menyebabkan penyakit, seperti diabetes, penyakit kardiovaskular (Romieu et al. 2017).

Penyebab obesitas dan kelebihan berat badan adalah ketidak seimbangan energi antara asupan kalori dan kalori keluar (Seo and Kim, 2019). Kelebihan berat badan menggambarkan keadaan tubuh tidak nomal sebagai akibat dari kelebihan lemak pada seseorang beresiko terhadap kesehatan. Perubahan berat dipengaruhi oleh jumlah energi yang dikeluarkan dan jumlah energi yang dikonsumsi. Penurunan berat badan akan tercapai dengan pembatasan kalori dan pelatihan olahraga (Jakicic et al. 2013).
Intervensi gaya hidup dalam
pengelolaan obesitas bertujuan untuk mendukung penurunan berat badan terutama melalui modifikasi asupan makanan dan aktivitas fisik. Modifikasi asupan makanan ini yaitu berupa defisit kalori. Pembatasan kalori disesuaikan dengan berat badan individu dan level aktivitas fisik, defisit kalori sebesar 20\%, agar terdapat perubahan signifikan dalam variabel komposisi tubuh (berat badan dan BMI). Defisit calori sebesar $15-25 \%$ dari TDEE dapat menurunkan lemak dan meningkatkan pemeliharaan ottot (Garthe et al. 2011).

Cara paling dasar untuk mengelola mencegah kelebihan berat badan dan obesitas adalah memilih makanan sehat dan memastikan aktivitas fisik (Chin, Kahathuduwa, and Binks 2016). Untuk pencegahan dan pengobatan obesitas dan sindrom metabolik telah direkomendasikan melakukan berbagai program latihan termasuk latihan aerobik, pelatihan resistensi dan fleksibilitas (Schwingshackl et al. 2013). Orang dewasa dengan kelebihan berat badan dan obesitas memerlukan aktivitas fisik 250 menit per minggu dengan intensitas sedang untuk menurunkan berat badan.

Latihan sirkuit merupakan solusi dalam mencegah obesitas, karena latihan merupakan kombinasi antara latihan resistensi dan aerobik (Contrò et al. 2017). Latihan sirkuit dengan lebih efektif dalam menurunkan berat badan dan obesitas (Umamaheswari et al, 2017), meningkatkan kekuatan otot dan fungsi kardiorespirasi (Marcos-pardo et al. 2019) dan memperbaiki komposisi tubuh (MartínezRodríguez et al. 2018). Program utama selama 65 menit serta joging pada intensitas $50-70 \%$, latihan sirkuit terdiri latihan ketahanan dan latihan aerobic (Starrett at al. 2014).

Hasil penelitian terdahulu yang telah dilakukan adalah tidak ada perubahan signifikan yang diamati untuk variabel komposisi tubuh setelah latihan sirkuit 8 minggu (Feito et al. 2019). Itu disebabkan 
tidak adanya kontrol asupan makanan selama durasi intervensi. Dalam penelitian ini dilakukan pengaturan diet agar mendapakan hasil terhadap variabel berat badan dan BMI.

Kejadian obesitas semakin meningkat, apabila tidak di cegah akan menimbulkan penyakit dan komplikasi berbahaya, perlu adanya perubahan gaya hidup agar obesitas dapat diatasi. Sampai saat ini banyak literatur yang meneliti sirkuit training, akan tetapi belum banyak yang meneliti sirkuit training di sertai pengaturan diet, maka dari itu, tujuan penelitian ini mengetahui pengaruh latihan sirkuit dan pengaturan diet terhadap berat badan dan BMI.

\section{METODE PENELITIAN}

Desain penelitian digunakan dalam penelitian ini adalah eksperimen (Fraenkel, Wallen, and Hyun, 2013). Populasi yang digunakan adalah wanita obesitas dan kelebihan berat badan dengan klasifikasi $\left(25 \mathrm{~kg} / \mathrm{m}^{2}-30 \mathrm{~kg} / \mathrm{m}^{2}\right)$ berjumlah 22 orang dan sampel dipilih dengan menggunakan teknik Purvosive Sampling, artinya pemilihan sampel berdasarkan pertimbangan dan kriteria tertentu yang ditentukan oleh peneliti (Sugiyono, 2013). sampel tersebut dibagi kedalam dua kelompok, yaitu kelompok eksperimen 11 orang (Latihan Sirkuit dan pengaturan diet) dan kelompok kontrol 11 orang (Latihan Sirkuit). Instrumen yang digunakan adalah berupa perhitungan Indeks Massa Tubuh (IMT) dengan rumus: Berat badan (dalam $\mathrm{kg}$ ) dibagi dengan kuadrat tinggi (dalam $\mathrm{m}^{2}$ ).

Peneliti melakukan program latihan sirkuit yang dimodifikasi. Kelompok eksperimen diberikan perlakuan Sirkuit Training dan pengaturan diet dan kelompok kontrol hanya diberikan latihan sirkuit saja tanpa pengaturan diet. Aktivitas sirkuit training dilakukan selama 8 minggu, dengan frekuensi 3 kali seminggu, durasi 65 menit latihan, metode yang dilakukan adalah 10 menit pemanasan, 30 menit lari di treadmil (40-60\% DNM), dan melakukan aktivitas
Sirkuit Training selama 25 menit, dengan 8 pos yang harus dilakukan, setiap pos diberi waktu 30 detik aktivitas dan 15 detik istirahat.

Intervensi pengaturan diet dilakukan dengan cara menghitung jumlah kebutuhan kalori perharinya (TDEE), melalui food record dalam aplikasi Nutrisurvey (Gizi, 2006). Lalu diberikan defisit kalori sebanyak 20\% dari total kebutuhan kalori perharinya. Setelah dihitung melalui aplikasi nutrisurvey didapat hasil kebutuhan kalori rata-rata subjek penelitian yaitu sebesar $2135 \mathrm{kcal} / \mathrm{hari}$, maka defisit kalori sebanyak $20 \%$ dari total kebutuhan kalori subjek penelitian yaitu sebesar $1718 \mathrm{kcal} / \mathrm{hari}$, defisit kalori 20\% termasuk dalam katagori defisit kalori sedang, dengan defisit kalori sebanyak 20\%, agar kebutuhan nutrisi tubuh masih bisa terpenuhi, rasa lapar akibat dari defisit kalori masih bisa diatasi, performa latihan sirkuit masih baik dan menjaga massa otot agar tidak hilang dan agar tubuh tetap sehat meskipun sedang melakukan defisit kalori. Maka dari itu subjek penelitian kelompok eksperimen di berikan pengaturan diet berupa asupan gizi sebanyak 1718 $\mathrm{kcal} / \mathrm{harinya}$. Tabel menu makanan diberikan sesuai dengan angka defisit kalori sebesar $1718 \mathrm{kcal} / \mathrm{hari}$.

Teknik analisis data yang digunakan adalah dengan penghitungan statistik dalam menguji hipotesis dilakukan dengan menggunakan SPSS 21.0

\section{HASIL DAN PEMBAHASAN Hasil}

Dari Tabel 1. diketahui skor rata-rata variabel berat badan pada kelompok eksperimen (latihan sirkuit dan pengaturan diet) pre test $73,6 \mathrm{~kg}$ dan pada post test $69,5 \mathrm{~kg}$ sedangkan pada kelompok kontrol (latihan sirkuit) pre test $70,2 \mathrm{~kg}$ dan pada post test $69,1 \mathrm{~kg}$ dan variabel BMI rata-rata pada kelompok eksperimen (latihan sirkuit dan pengaturan diet) pre test $29,89 \mathrm{~kg} / \mathrm{m}^{2}$ dan pada post test $28,24 \mathrm{~kg} / \mathrm{m}^{2}$ sedangkan pada 
kelompok kontrol (latihan sirkuit) pre test $29,07 \mathrm{~kg} / \mathrm{m}^{2}$ dan pada post test $28,64 \mathrm{~kg} / \mathrm{m}^{2}$. Tabel 1 Hasil Untuk Variabel Berat Badan dan BMI

\begin{tabular}{clccc}
\hline \multicolumn{1}{c}{ Variabel } & \multicolumn{1}{c}{ Grup } & Pre & Post & Sig (2-tailed) \\
\hline Berat Badan $(\mathrm{Kg})$ & Eksperimen & $73,6 \pm 8,6$ & $69,5 \pm 6,7^{*}$ & $(0,003<0,05)$ \\
& Kontrol & $70,1 \pm 1,4$ & $69,1 \pm 1,3^{*}$ & $(0,000<0,05)$ \\
BMI $\left(\mathrm{Kg} / \mathrm{m}^{2}\right)$ & Eksperimen & $29,9 \pm 3,05$ & $28,2 \pm 2,3^{*}$ & $(0,003<0,05)$ \\
& Kontrol & $29,0 \pm 0,5$ & $28,6 \pm 0,6^{*}$ & $(0,003<0,05)$ \\
\hline
\end{tabular}

Dari hasil analisis didapatkan hasil bahwa terdapat perbedaan yang signifikan antara berat badan pretest dan posttest pada kelompok eksperimen dengan nilai Sig. $(0,003<0,05)$. Dapat dilihat pada Gambar 1.

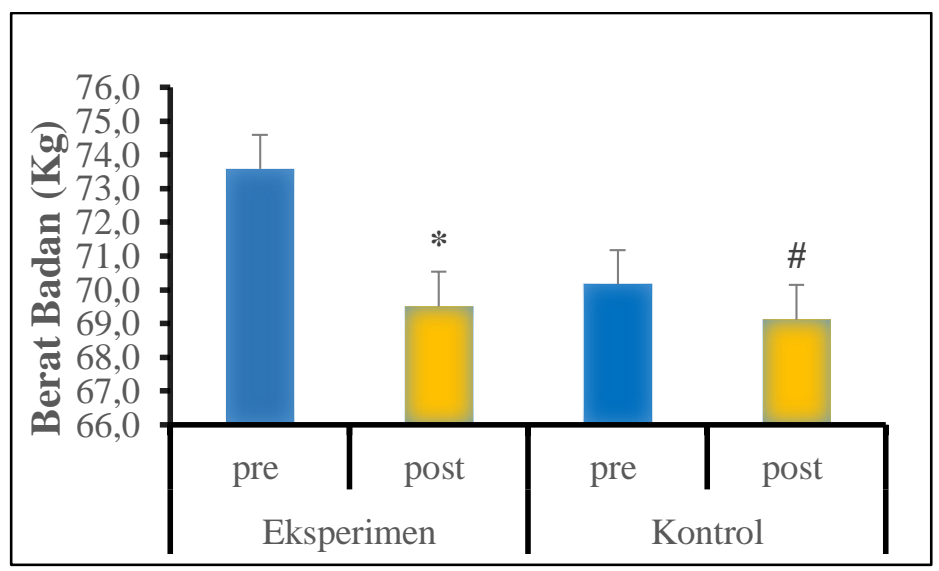

Gambar 1. Hasil Penurunan Berat Badan (Kg) Pretest dan Posttest pada kelompok eksperimen dan kontrol *, \# menunjukan signifikan $\mathrm{p}<0.5$ dibandingkan dengan kelompok pretes masing-masing kelompok

Pada Gambar 2. Menunjukan bahwa latihan sirkuit training dengan Sig. $(0,003<$ terdapat perbedaan yang signifikan pada BMI kelompok eksperimen setelah dilakukan $0,05)$

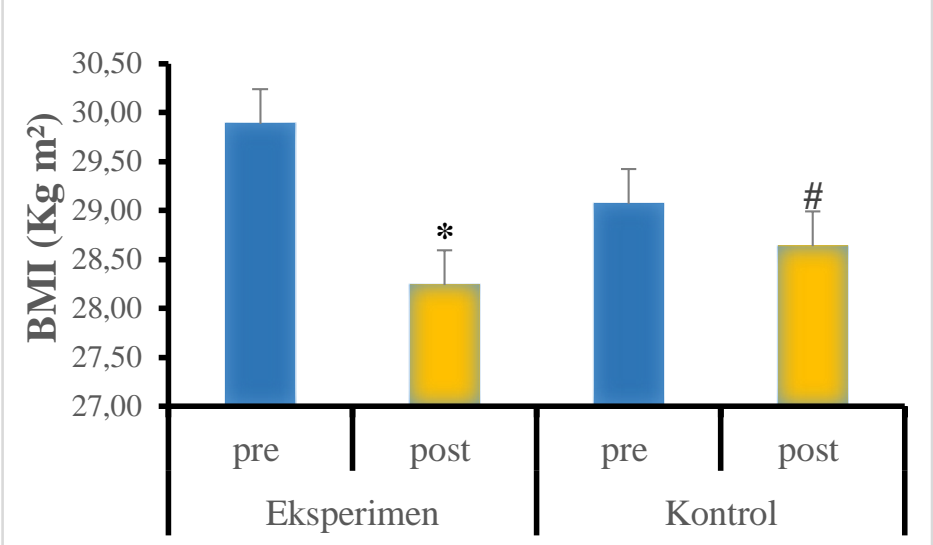

Gambar 2. Hasil Penurunan BMI $\left(\mathrm{Kg} / \mathrm{m}^{2}\right)$ Pretest dan Posttest pada kelompok eksperimen dan kelompok kontrol. *, \# menunjukan signifikan $\mathrm{p}<0.5$ dibandingkan dengan kelompok pretes masingmasing kelompok 


\section{Pembahasan}

Berdasarkan hasil temuan penelitian, bahwa latihan sirkuit dan pengaturan diet selama 8 minggu berpengaruh terhadap berat badan pada wanita obesitas. Hal ini senada bahwa Latihan sirkuit berpengaruh terhadap penurunan berat badan dan indeks massa tubuh pada wanita obesitas (Kim et al., 2018). Latihan sirkuit selama 10 minggu secara signifikan menurunkan berat badan dan persentase lemak (Yoshimura et al., 2016). Lemak bisa terbakar setelah 30 menit berlatih, ini merujuk pada sistem pembentukan daya, bahwa 1-2 detik ATP, 10-20 detik ATP-PC, 13 menit glikogen, kurang dari 30 menit oksidasi laktat, lebih dari 30 menit oksidasi lemak (Griwijoyo, 2012). Dalam penelitian ini intervensi latihan dilakukan selama 65 menit berupa latihan gabungan aerobik dan resisten, sehingga berpengaruh terhadap penurunan berat badan.

Hasil penelitian ini pun menemukan bahwa Latihan sirkuit dan pengaturan diet memiliki pengaruh terhadap BMI pada wanita obesitas. Hal ini senada dengan intervensi pengaturan diet dan olahraga secara signifikan dapat mengurangi rata-rata BMI pada penderita obesitas stadium 1 dari (BMI 30-35) menjadi (BMI 25-29,9) (Kleist et al., 2017). Latihan selama 8 minggu dapat signifikan menurunkan BMI dan berat badan (Salesi and Gani, 2018). Latihan sirkuit terdiri dari 50 menit latihan tiga kali per minggu adalah metode yang efektif untuk pengurangan BMI ( $\mathrm{kg} / \mathrm{m} 2)$ pada wanita obesitas (Madureira et al., 2012).

Dengan latihan sirkuit training dapat membantu dalam memperbaiki komposisi tubuh dan sebagai cara yang efektif untuk pengobatan obesitas. Pengurangan berat badan dan massa lemak pada wanita gemuk dihasilkan dari disiplin latihan yang konsisten (Miyamoto-mikami et al., 2015). Faktor istirahatpun sangat penting dalam penurunan berat badan. Hal ini senada dengan tidur yang cukup selama 7 jam dalam satu hari dapat meningkatkan hasil penurunan lemak tubuh (Wang et al. 2018). Akan tetapi ketika kurang tidur akan menyebabkan kenaikan berat badan (Markwald et al., 2013) dan meningkatkan nafsu makan (Brondel et al., 2010). Selain faktor latihan dan istirahat dapat menurunkan berat badan dan BMI, faktor nutrisi pun sangat penting. Dengan mengkonsumsi kacangkacangan, termasuk makanan gandum sereal, sayuran, dan buah-buahan, dapat menekan obesitas dan penambahan berat badan (Fogelholm and Anderssen, 2015). Keuntungan asupan protein dalam penurunan berat badan dan pemeliharaan berat badan, dapat meningkatkan rasa kenyang (Leidy et al., 2015). Sehingga ketika rasa kenyang meningkat, asupan kalori yang masuk kedalam tubuh akan dapat dikendalikan.

Asupan kalori adalah variabel penting untuk kehilangan lemak. Konsisten dan kesabaran merupakan kunci dalam keberhasilan mengurangi obesitas, sehingga latihan sirkuit dan pengaturan diet akan dijadikan kebutuhan dan gaya hidup pada wanita obesitas.

Dalam penelitian ini tidak ada pengawasan makanan untuk kelompok kontrol (latihan sirkuit saja), subjek penelitian dibiarkan makan tanpa adanya pengawasan. Intervensi latihan sirkuit pada kelompok eksperimen (latihan sirkuit dan pengaturan diet) dan pada kelompok kontrol (latihan sirkuit) diberikan dengan program latihan sirkuit yang sama dan itu menjadi salah satu faktor terjadinya hasil yang signifikan pada kedua kelompok tersebut.Tingkat pengetahuan yang baik pada subjek penelitan terhadap kesehatan menjadi faktor signifikan tehadap hasil penurunan berat badan dan BMI dalam kelompok kontrol, diluar penelitian kelompok kontrol membatasi asupan makanan sehingga berpengaruh terhadap hasil penelitian, akan tetapi secara hasil kelompok eksperimen (latihan sirkuit dan pengaturan diet) menunjukan hasil penurunan berat bandan dan 
BMI yang lebih besar di bandingkan kelompok kontrol (latihan sirkuit saja). Oleh karena itu latihan sirkuit dan pengaturan diet dianggap sebagai latihan yang relevan untuk menurunkan berat badan dan BMI pada wanita obesitas.

\section{SIMPULAN}

Hasil dari penelitian ini didapatkan bahwa terdapat pengaruh latihan sirkuit dan pengaturan diet terhadap berat badan dan BMI pada wanita obesitas. Maka dari itu latihan sirkuit dan pengaturan diet metode paling efektif dalam penurunan berat badan dan BMI pada wanita obesitas.

Saran penetian ini diharapkan wanita obesitas membiasakan diri melakukan olahraga dan pengaturan diet yang konsisten, agar lebih aktif dan mendapatkan derajat hidup sehat yang lebih baik. Kepada para pelatih fitness dan pelatih kebugaran agar dapat memberikan pengaturan diet berupa defisit kalori 20\% karena dapat menurunkan berat badan dan BMI pada wanita obesitas. Kepada para wanita obesitas agar membuat jurnal makanan, karena dengan jurnal makanan akan membatasi sumber makanan sehingga akan menghindarkan dari makanan berlebih. Kepada para pelatih kebugaran agar memberikan pengetahuan makanan yang baik untuk di konsumsi dan makanan yang harus dihindari penderita obesitas. Dengan demikian latihan sirkuit dapat menurunkan berat badan dan BMI, akan tetapi salah satu faktor kunci dalam keberhasilan penurunan berat badan dan BMI adalah pengaturan diet dengan cara defisit kalori sebesar $20 \%$.

\section{UCAPAN TERIMA KASIH}

Terimakasih terhadap Fitness View Bandung yang menyediakan tempat penelitian, terimakasih kepada subjek penelitian yang telah bersedia mengikuti berjalannya penelitian ini.

\section{DAFTAR PUSTAKA}

Brondel, Laurent et al. 2010. "Acute Partial Sleep Deprivation Increases Food Intake in Healthy Men 1 - 3." (March).

Chin, S, C N Kahathuduwa, and M Binks. 2016. "Physical Activity and Obesity: What We Know and What We Need to Know." (3).

Communications, Special. 2009. “Appropriate Physical Activity Intervention Strategies for Weight Loss and Prevention of Weight Regain for Adults." 109(2): 459-71.

Contrò, Valentina et al. 2017. "Effects of Different Circuit Training Protocols on Body Mass , Fat Mass and Blood Parameters in Overweight Adults on $\mathrm{m}$ Er Ci Al Us e on on Om m Er." 90.

Feito, Yuri et al. 2019. "Effects of Eight Weeks of High Intensity Functional Training on Glucose Control and Body Composition among Overweight and Obese Adults." Sports 7(2): 51. http://www.mdpi.com/2075$4663 / 7 / 2 / 51$.

Flegal, Katherine M, Margaret D Carroll, Cynthia L Ogden, and Lester R Curtin. 2013. "CLINICIAN ' S CORNER Among US Adults , 1999-2008." 303(3): 235-41.

Fogelholm, Mikael, and Sigmund Anderssen. 2015. "Review." 1.

Fraenkel, J. R., N. E. Wallen, and H.H. Hyun. 2013. 53 Climate Change 2013 - The Physical Science Basis BIBLIYOGRAFISI Bulunacak. http://ebooks.cambridge.org/ref/id/CBO 9781107415324A009. 
Garthe, Ina et al. 2011. "Effect of Two Different Weight-Loss Rates on Body Composition and Strength and PowerRelated Performance in Elite Athletes." : 97-104.

Gizi, Profesi. 2006. "Panduan Singkat."

Gregg, Edward W, D Ph, and Jonathan E Shaw. 2017. "Edi t or i a 1 Global Health Effects of Overweight and Obesity." : 1-2.

Giriwijoyo, S. dan Sidik, D.Z. (2013). Ilmu Faal Olahraga (Fisiologi Olahraga): Fungsi Tubuh Manusia pada Olahraga untuk Kesehatan dan Prestasi. Bandung: Remaja Rosdakar

Helms, Eric R, Alan A Aragon, and Peter J Fitschen. 2014. "Evidence-Based Recommendations for Natural Bodybuilding Contest Preparation: Nutrition and Supplementation." : 1-20.

Hill, James O et al. 2012. "Energy Balance and Obesity Energy Balance: Definitions." : 126-32.

Hunter, Gary R et al. 2018. "Reduction in Intra-Abdominal Adipose Tissue after Strength Training in Older Women."

Jakicic, John M, Bess H Marcus, Kara I Gallagher, and Melissa Napolitano. 2013. "Effect of Exercise Duration and Intensity on Weight Loss in Overweight , Sedentary Women." 290(10): 132330 .

Kesehatan, Kementerian. 2018. "HASIL UTAMA RISKESDAS 2018."

Kim, Ji-woon, Yeong-chan Ko, Tae-beom Seo, and Young-pyo Kim. 2018. "Effect of Circuit Training on Body Composition, Physical Fitness, and
Metabolic Syndrome Risk Factors in Obese Female College Students." 14(3): 460-65.

Kleist, Bernadette et al. 2017. "Moderate Walking Enhances the Effects of an Energy-Restricted Diet on Fat Mass Loss and Serum Insulin in Overweight and Obese Adults in a 12-Week Randomized Controlled Trial.” (C): 110.

Leidy, Heather J et al. 2015. "The Role of Protein in Weight Loss and Maintenance 1 - 5." (C).

Madureira, Angelo et al. 2012. "Effects of Circuit-Based Exercise Programs on the Body Composition of Elderly Obese Women." : 551-56.

Marcos-pardo, Pablo Jorge et al. 2019. "Effects of a Moderate-to-High Intensity Resistance Circuit Training on Fat Mass , Functional Capacity , Muscular Strength, and Quality of Life in Elderly: A Randomized Controlled Trial." (November 2018): 1-12.

Markwald, Rachel R et al. 2013. "Impact of Insuf Fi Cient Sleep on Total Daily Energy Expenditure , Food Intake, and Weight Gain.”

Martínez-Rodríguez, Alejandro, José M. García De Frutos, Pablo J. MarcosPardo, and Javier Orquín-Castrillón. 2018. "Frequency of High Intensity Circuit Training and Diet. Effects on Performance and Health in Active Adults: Randomized Controlled Trial." Archivos de Medicina del Deporte 35(2): 73-79.

Miyamoto-mikami, Eri, Koji Sato, Toshiyuki Kurihara, and Natsuki Hasegawa. 2015. "Endurance Training-Induced Increase 
in Circulating Irisin Levels Is Associated with Reduction of Abdominal Visceral Fat in Middle-Aged and Older Adults." : 2-13.

Ng, Marie et al. 2014. "Global, Regional, and National Prevalence of Overweight and Obesity in Children and Adults during 1980 - 2013 : A Systematic Analysis for the Global Burden of Disease Study 2013." 384.

Romieu, Isabelle et al. 2017. "Energy Balance and Obesity: What Are the Main Drivers?" Cancer Causes and Control 28(3): 247-58.

Salesi, Mohsen, and Shakiba Gani. 2018. "Effects of Exercise Intervention to Improve Body Composition and Chemerin in Middle-Aged Overweight Women." 2(2): 1-12.

Schwingshackl, Lukas, Sofia Dias, Barbara Strasser, and Georg Hoffmann. 2013. "Impact of Different Training Modalities on Anthropometric and Metabolic Characteristics in Overweight / Obese Subjects : A Systematic Review and Network Meta-Analysis." 8(12).

Seo, Young Gyun, and Soo Young Kim. 2019. "Weight Loss Effects of Circuit
Training Interventions: A Systematic Review and Meta - Analysis." (June): $1-9$.

Starrett, Kelly, Glen Cordoza, and Paul D Thompson. 2014. "Book Reviews." 58(3): 328-29.

Sugiyono. (2014). Metode Penelitian Kuantitatif Kualitatif dan R \& D. Bandung : CV Alpabeta.

Umamaheswari, K, Y Dhanalakshmi, S Karthik, and Nitin Ashok John. 2017. "Original Article Effect of Exercise Intensity on Body Composition in Overweight and Obese Individuals." (1): 58-64.

Wang, Xuewen, Joshua R Sparks, Kimberly P Bowyer, and Shawn D Youngstedt. 2018. "Influence of Sleep Restriction on Weight Loss Outcomes Associated with Original Article Influence of Sleep Restriction on Weight Loss Outcomes Associated with Caloric Restriction." (October).

Yoshimura, Yoshitaka, Hiroyuki Nakamura, and Mihoko Shimomura. 2016. "Journal of Athletic Effects of High-Intensity Circuit Training on Calcaneal Bone Status in Collegiate Women." : 2-5. 